\title{
The Incidence of Methemoglobinemia Due to Prilocaine Use in Circumcision
}

\section{Prilokain ile Yapılan Sünnetlerde Methemoglobinemi Insidansı}

\author{
(D) Deniz Arslan1, (D) Güner Yıldız1, (D) Mehmet Oğuz Şahin² \\ 1 University of Health Sciences, Izmir Dr. Suat Seren Chest Diseases and Surgery Training and Research Hospital, Clinic of Urology, Izmir, Turkiye \\ 2Manisa State Hospital, Clinic of Urology, Manisa, Turkiye
}

\section{What's known on the subject? and What does the study add?}

Prilocaine is more frequently encountered as a cause of acquired methemoglobinemia in newborns and children compared to adults. Determining the causative factor for methemoglobinemia and undertaking early and effective application of methylene blue or ascorbic acid can be life-saving.

\begin{abstract}
Objective: Local anesthesia with prilocaine is widely used in circumcision procedures. However, the incidence of methemoglobinemia due to prilocaine use during these procedures remains unknown. Therefore, this retrospective study was planned to determine the possibility of development of prilocaine-associated methemoglobinemia during circumcision.

Materials and Methods: Medical records of 2.431 patients who were circumcised between 2008 and 2015 in University of Health Sciences, İzmir Dr. Suat Seren Chest Diseases and Surgery Training and Research Hospital, Turkiye, were evaluated. Prior to all circumcision procedures, $1.5 \mathrm{mg} / \mathrm{kg}$ of local anesthetic was subcutaneously administered to the penis root at 4-5 points from a $20 \mathrm{~mL}$ vial containing $400 \mathrm{mg}(20 \mathrm{mg} / \mathrm{mL})$ of prilocaine $(2 \%)$.

Results: Of the 2.431 patients included in the study, two $(0.008 \%)$ developed methemoglobinemia requiring treatment. According to the medical records, five patients $(0.021 \%)$ developed mild bruising on the hands, feet and sides of the lips.

Conclusion: Prilocaine is more frequently encountered as a cause of acquired methemoglobinemia in newborns and children compared to adults. Determining the causative factor for methemoglobinemia and undertaking early and effective application of methylene blue or ascorbic acid can be life-saving.
\end{abstract}

Keywords: Prilocaine, Circumcision, Methemoglobinemia, Local anesthesia, Complications

\section{Öz}

Amaç: Sirkümsizyon işleminde prilokain ile lokal anestezi uygulaması yaygın olarak kullanılmaktadır. Sirkümsizyon esnasında prilokain kullanımına bağlı methemoglobinemi insidansı bilinmemektedir. Bu retrospektif çalışma sirkümsizyon sırasında kullanılan prilokaine bağlı methemoglobinemi gelişme olasılığını ortaya koymak amacıyla planlanmıştır.

Gereç ve Yöntem: Sağlık Bilimleri Üniversitesi, İzmir Dr. Suat Seren Göğüs Hastalıkları ve Cerrahisi Eğitim ve Araştırma Hastanesi, Üroloji Kliniği'ne 2008-2015 arasında gelen 2431 hastanın dosyaları incelendi. Tüm sirkümsizyon işlemlerinden önce, $20 \mathrm{~mL}$ 'lik her flakonda $400 \mathrm{mg}$ (20 mg/mL) prilokain (\%2) içeren lokal anestezik 1,5 mg/kg olarak penis köküne 4-5 noktadan deri altına uygulandı.

Bulgular: Sağlık Bilimleri Üniversitesi, İzmir Dr. Suat Seren Göğüs Hastalıkları ve Cerrahisi Eğitim ve Araştırma Hastanesi, Üroloji Kliniği'ne $2008-2015$ arasında gelen 2431 hastanın dosyaları incelendi. Çalışmaya dahil edilen 2431 hastadan iki hastada $(\% 0,008)$ tedavi gerektiren methemoglobinemi gelişti. Beş hastada $(\% 0,021)$ ise el, ayak ve dudak kenarlarında hafif düzeyde morarma olduğu anamnezde tespit edildi.

Sonuç: Yenidoğan ve çocuklarda edinsel methemoglobinemi olgularının erişkine oranla görece sık methemoglobinemi sebeplerinden biri olarak karşımıza çıkmıştır. Methemoglobinemiye neden olan faktörün saptanması, erken ve etkin şekilde askorbik asit veya metilen mavisi uygulanması yaşam kurtarıcı olmaktadır.

Anahtar Kelimeler: Prilokain, Sirkümsizyon, Methemoglobinemi, Lokal anestezi, Komplikasyon

Correspondence: Güner Yıldız MD, University of Health Sciences, İzmir Dr. Suat Seren Chest Diseases and Surgery Training and Research Hospital, Clinic of Urology, İzmir, Turkiye

Phone: +90 5054758587 E-mail: drgyildiz@yahoo.com.tr ORCID-ID: orcid.org/0000-0002-0495-9863

Received: 13.08 .2018

Accepted: 05.09.2018

Cite this article as: Arslan D, Yıldız G, Şahin M0. The Incidence of Methemoglobinemia Due to Prilocaine Use in Circumcision. J Urol Surg 2019;6(1):38-41.

๑Copyright 2019 by the Association of Urological Surgery / Journal of Urological Surgery published by Galenos Publishing House. 


\section{Introduction}

Circumcision is one of the most widespread procedures in the world undertaken for religious reasons among Muslims and Jews and for hygienic or pathological phimosis-related medical conditions in males. Although circumcision can be performed with patients under general anesthesia, some surgeons prefer local anesthesia. In both cases, local anesthesia is applied around the penis to reduce pain during or after circumcision. With its short-acting profile in infiltration anesthesia, prilocaine is one of the most commonly used amide-type local anesthetics. Allergic reactions, such as edema, urticaria, dermatitis, and pallor are among the predominant side effects from low-dose prilocaine infiltration (1). One of the less frequently seen side effects is methemoglobinemia. Hemoglobin $(\mathrm{Hb})$ is a molecule found in the erythrocytes that transport $\mathrm{O}_{2}$ to tissues. For this process, the iron in the structure of $\mathrm{Hb}$ must be in the $\mathrm{Fe}^{+2}$ form. Methemoglobinemia occurs when this iron becomes $\mathrm{Fe}^{+3}$, resulting in various oxidative stresses. Methemoglobin (MetHb) cannot carry $\mathrm{O}_{2}$ and shifts the $\mathrm{Hb}-\mathrm{O}_{2}$ dissociation curve to the left, making it more difficult for $\mathrm{O}_{2}$ to be delivered to the tissues. However, its concentration is reduced to less than $1 \%$ by the cytochrome-b5 reductase enzyme system; namely, the intracellular MetHb reductive system. Infants are more susceptible to oxidation since their cytochrome-b5 reductase enzyme levels are $50 \%$ lower than in adults (2). When the blood MetHb level is about 10-15\%, cyanosis develops, and if it exceeds $35 \%$, systemic symptoms including fatigue due to tissue hypoxia, tachycardia, respiratory distress, nausea, and vomiting occur. In cases where the blood MetHb level is 55\% or above, lethargy, stupor and syncope develop, and if it is over $70 \%$ and treatment action is not taken, then it usually results in death (3).

Methemoglobinemia can be congenital or acquired. There are four types of congenital methemoglobinemia, all of which result from inherited autosomal recessive disorders in various enzyme systems. To date, many chemicals and drugs have been reported to cause acquired methemoglobinemia, including nitrotoluenes, phenacetin, chloroquine, dapsone, phenytoin, sulfonamides, and local anesthetics. Methemoglobinemia due to the treatment dose of prilocaine as a local anesthetic is very rare (4).

The exact incidence of methemoglobinemia is not known. Our clinic is one of the centers in which circumcision has been widely practiced for many years. This retrospective study was planned to determine the incidence of methemoglobinemia due to prilocaine in our patients.

\section{Materials and Methods}

Ethics approval by the institutional review board of our hospitals had been obtained for data collection and analysis (number: 21/02/2018/1771). Before POP surgery, all patients were requested to sign an informed consent approved by the Institutional Review Board of University of Health Sciences, İzmir Dr. Suat Seren Chest Diseases and Surgery Training and Research Hospital. Medical records of 2.431 patients circumcised between 2008 and 2015 in University of Health Sciences, İzmir Dr. Suat Seren Chest Diseases and Surgery Training and Research Hospital, Turkiye were evaluated retrospectively. The mean age of the patients was 7.2 years (ranging from 14 days to 13 years). None of the patients had any additional disease. Furthermore, no pathology had been detected during prenatal follow-ups or delivery. Prior to all circumcision procedures, $1.5 \mathrm{mg} / \mathrm{kg}$ of local anesthetic was subcutaneously administered to the penis root at 4-5 points from a $20 \mathrm{~mL}$ vial containing $400 \mathrm{mg}(20 \mathrm{mg} /$ $\mathrm{mL}$ ) of prilocaine (2\%). All surgeries were performed under local anesthesia.

\section{Results}

Of the 2.431 patients included in the study, two $(0.008 \%)$ developed methemoglobinemia requiring treatment. According to the medical records, five patients $(0.021 \%)$ developed mild bruising on the hands, feet and sides of the lips. However, no medical interventions were undertaken for these five patients since there was no problem in their general condition.

Case 1 was a 105-day-old infant who was hospitalized for the treatment of methemoglobinemia that developed after circumcision. He had been delivered via spontaneous vaginal route and had a birth weight of $3.100 \mathrm{~g}$. Early circumcision was planned due to phimosis, but he had no other health problems in the previous 105 days. Two hours after circumcision, the parents brought the infant to the emergency department with the complaint that the whole body of the infant was bruised. On arrival, the child's blood pressure was $85 / 55 \mathrm{mmHg}$, respiratory rate was $33 / \mathrm{min}$, and heart rate was $130 / \mathrm{min}$. $\mathrm{SO}_{2}$ was measured as $70 \%$ using a pulse oximeter. Arterial blood gas $\mathrm{pH}$ was 7.43 , $\mathrm{HCO}_{3}$ was $20 \mathrm{mEq} / \mathrm{L}, \mathrm{PCO}_{2}$ was $36 \mathrm{mmHg}$, and $\mathrm{PO}_{2}$ was $94 \mathrm{mmHg}$. The MetHb level was 41.5\%. According to the complete blood count analysis, the $\mathrm{Hb}$ level was $11.2 \mathrm{~g} / \mathrm{dL}$, hematocrit was $34.6 \%$, and thrombocyte was $245000 / \mathrm{mm}^{3}$. Based on these findings, methemoglobinemia was considered, and $100 \mathrm{mg} /$ day of ascorbic acid and methylene blue was administered to the patient via $1 \mathrm{cc} / \mathrm{kg} /$ dose intravenous infusion from a $1 \%$ solution. Thirty minutes after the administration of methylene blue, $\mathrm{pH}$ was measured as $7.36, \mathrm{HCO}_{3}$ as $22 \mathrm{mEq} / \mathrm{L}, \mathrm{PCO}_{2}$ as 34.3 $\mathrm{mmHg}, \mathrm{PO}_{2}$ as $98 \mathrm{mmHg}$, and MetHb as $5.4 \%$. At this stage, the patient's cyanosis completely resolved, and he had a normal 
glucose-6-phosphate dehydrogenase (G6PD) level. The patient was monitored for 24 hours and discharged without cyanosis and with all vital signs stabilized.

Case 2 was a 35-day-old infant delivered through vaginal route weighing $2.950 \mathrm{~g}$. Circumcision had been planned in the early period due to the development of pathological phimosis with no other health problems occurring in the first 35 days. Approximately one hour after circumcision, he was admitted to the emergency department due to his entire body being bruised. Upon admission, his blood pressure was $90 / 55 \mathrm{mmHg}$, respiratory rate was $34 / \mathrm{min}$, and heart rate was $126 / \mathrm{min}$. $\mathrm{SO}_{2}$ was found to be $72 \%$ using a pulse oximeter. Arterial blood gas $\mathrm{pH}$ was 7.37 , $\mathrm{HCO}_{3}$ was $20 \mathrm{mEq} / \mathrm{L}, \mathrm{PCO}_{2}$ was $36 \mathrm{mmHg}$, and $\mathrm{PO}_{2}$ was $95 \mathrm{mmHg}$. The MetHb level was measured as $42 \%$. Complete blood count assessment showed that the $\mathrm{Hb}$ level was $11.0 \mathrm{~g} / \mathrm{dL}$, hematocrit was $33.2 \%$, and thrombocyte was $215000 / \mathrm{mm}^{3}$. These findings indicated methemoglobinemia; thus, $100 \mathrm{mg} /$ day of ascorbic acid and methylene blue was administered to the patient via intravenous infusion as $1 \mathrm{cc} / \mathrm{kg} /$ dose of a $1 \%$ solution. Thirty minutes after methylene blue was administered, $\mathrm{pH}$ was found to be $7.36, \mathrm{HCO}_{3} 21 \mathrm{mEq} / \mathrm{L}, \mathrm{PCO}_{2} 35.4 \mathrm{mmHg}, \mathrm{PO}_{2} 97 \mathrm{mmHg}$, and MetHb level 5.6\%. At this time, the patient's cyanosis had completely resolved. The patient also had a normal G6PD level. After being observed for a further 24 hours, the patient was discharged without cyanosis and with all vital signs stable.

Five other patients aged 14 days, 43 days, 63 days, 82 days and 1.5 years were found to have mild bruising only in hands and feet, and, thus, were diagnosed with methemoglobinemia. All these patients were discharged without any medical intervention after close observation in which no complication was identified.

\section{Discussion}

Methemoglobinemia can be seen in two forms, congenital or acquired. The diagnosis of congenital methemoglobinemia is based on the level of the intracellular cytochrome b5 reductase enzyme. A large number of agents are known to cause the development of acquired methemoglobinemia with most implicated examples being sulfonamides, local anesthetic drugs, and nitrate-containing vegetables (5). Circumcision is a commonly performed religious practice in Turkiye, and prior to this procedure, prilocaine is generally used to manage pain.

Four types of local anesthetics have been reported to cause methemoglobinemia; prilocaine, benzocaine, lidocaine, and tetracaine. It is well known that ortho-toluidine, a metabolite of prilocaine, leads to $\mathrm{Hb}$ oxidation $(6,7)$. In clinical practice, the injectable form of prilocaine (Citanest ${ }^{\circ}$ ) and prilocaine-lidocaine $\left(E M L A^{\circ}\right)$ cream are the two most commonly used commercial preparations. At therapeutic doses (1-2 $\mathrm{mg} / \mathrm{kg} /$ dose), prilocaine causes MetHb formation at levels that are usually too low to induce cyanosis, however, the risk of methemoglobinemia increases with the increased dose $(8,9)$.

The main reasons why children are more susceptible to methemoglobinemia include inadequate soluble form of the nicotinamide adenine dinucleotide (NADH)-cytochrome b5 reductase enzyme, which deoxidizes MetHb and facilitates oxygen transport, fetal $\mathrm{Hb}$ being more sensitive to oxidation, and intestinal colonization with nitrate-producing bacteria. The risk of developing methemoglobinemia is higher particularly in newborns and infants since their MetHb reductase enzyme activity is low $(10,11)$. However, in the literature, the development of methemoglobinemia has also been reported after topical use of local anesthetics at therapeutic doses, as in our patients $(12,13)$.

Methemoglobinemia associated with local anesthetics can lead to life-threatening conditions (e.g., coma, seizures, respiratory depression, and shock) and permanent damage (e.g., hypoxic encephalopathy and myocardial infarction), and even death (14). Congenital heart diseases, pulmonary diseases, anemia and serious infections should be considered in the differential diagnosis of cases presenting with cyanosis suspected of having methemoglobinemia. In the absence of heart and lung diseases, cyanosis that does not respond to high-flow $\mathrm{O}_{2}$ should be considered as an indication of methemoglobinemia. MetHb is normally formed in small quantities and is rapidly destroyed by the NADH-MetHb reductase (cytochrome b5 reductase) enzyme in the erythrocytes, however, congenital methemoglobinemia patients have a deficiency of this enzyme. "NADPH-MetHb reductase" is another MetHb reductase enzyme system that uses NADPH as a cofactor. This system is physiologically inactive but it becomes active in the presence of redox components. The mechanism of action of methylene blue in the treatment of methemoglobinemia is through the NADPH-MetHb reductase system. NADPH required for an effective treatment is derived from the hexose monophosphate pathway, therefore, the G6PD level should be normal $(15,16)$. Thus, in individuals with G6PD deficiency, methylene blue does not have a role in the treatment of methemoglobinemia.

Since the G6PD level seen in our patients was normal, the methylene blue treatment was beneficial. In the treatment, the main objective is to terminate the application of the agent, which is primarily responsible for the condition. If the level of MetHb is less than $20 \%$, recovery can be achieved by stopping the causative drug, but newborns and infants may still require treatment. If the MetHb level is greater than $70 \%$, hyperbaric $\mathrm{O}_{2}$ therapy and exchange transfusion can be undertaken $(17,18)$. Since case 1 was an infant with a MetHb value of $41.5 \%$ and his cyanosis did not improve after the application of methylene blue, we administered $100 \mathrm{mg} /$ day ascorbic acid. Since cyanosis continued to be observed, without waiting for an ascorbic acid 
response, 1\% methylene blue was applied by slow infusion under monitoring. Approximately half an hour after the administration of methylene blue, cyanosis was reduced and the MetHb level decreased to $5.4 \%$. It should also be noted that ascorbic acid can be safely used in the treatment of methemoglobinemia when methylene blue is not available.

\section{Conclusion}

As a local anesthetic, prilocaine is more frequently encountered as a cause of acquired methemoglobinemia in newborns and children compared to adults. Determining the causative factor for methemoglobinemia and undertaking early and effective application of methylene blue or ascorbic acid can be lifesaving.

\section{Ethics}

Ethics Committee Approval: The approval was obtained from University of Health Sciences, İzmir Dr. Suat Seren Chest Diseases and Surgery Training and Research Hospital (number: 21/02/2018/1771).

Informed Consent: Written informed consent was obtained from all patients.

Peer-review: Externally peer-reviewed.

\section{Authorship Contributions}

Surgical and Medical Practices: D.A., G.Y., Concept: D.A., Design: D.A., M.O.Ş., Data Collection or Processing: D.A., G.Y., M.O.Ş., Analysis or Interpretation: D.A., M.O.Ş., Literature Search: D.A., M.O.Ş., Writing: D.A., G.Y., M.O.Ş.

Conflict of Interest: No conflict of interest was declared by the authors.

Financial Disclosure: The authors declared that this study received no financial support.

\section{References}

1. Lui KC, Chow YF. Safe use of local anaesthetics: prevention and management of systemic toxicity. Hong Kong Med J 2010;16:470-475.
2. Trapp L, Will J. Acquired methemoglobinemia revisited. Dent Clin North Am 2010;54:665-675.

3. Benini $D$, Vino $L$, Fanos V. Acquired methemoglobinemia: $A$ case report. Pediatr Med Chir 1998;20:411-413.

4. Coleman MD, Coleman NA. Drug induced methaemoglobinemia. Drug Safety 1996;14:394-405.

5. Kreutz RW, Kinni ME. Life-threatening toxic methemoglobinemia induced by prilocaine. Oral Surg Oral Med Oral Pathol 1983;56:480-482.

6. Liao YP, Hung DZ, Yang DY. Hemolytic anemia after methylene blue therapy for aniline-induced methemoglobinemia. Vet Hum Toxicol 2002;44:19-21.

7. Kara A, Yigit $S$, Aygün C, Oran 0. Toxic methemoglobinemia after injection of prilocaine in a newborn. Turk J Pediatr 1998;40:589-592.

8. Nishimura K. Methemoglobinemia due to local anesthetics. Osaka City Med J 1971;17:25-42.

9. Taddio A, Stevens B, Craig K, Rastogi P, Ben-David S, Shennan A, Mulligan P, Koren G. Efficacy and safety of lidocaine-prilocaine cream for pain during circumcision. N Engl J Med 1997;336:1197-1201.

10. Moore PA, Hersh EV. Local anesthesia toxicity review revisited. Pediatr Dentistry 2000;22:7-8.

11. Nilsson A, Engberg G, Henneberg $\mathrm{S}$, Danielson $\mathrm{K}$, De Verdier $\mathrm{CH}$. Inverse relationship between age - dependent erythrocyte activity of methaemoglobin reductase and prilocaine-induced methaemoglobinaemia during infancy. Br J Anaesthesia 1990;64:72-76.

12. Kumar AR, Dunn N, Naqvi M. Methemoglobinemia associated with a prilocainelidocaine cream. Clin Pediatr 1997;36:239-240.

13. Gunter JB. Benefit and risks of local anesthetics in infants and children. Pediatr Drugs 2002;4:649-672.

14. Frey B, Kehrer B. Toxic methaemoglobin concentrations in premature infants after application of a prilocaine containing cream and peridural prilocaine. Eur J Pediatr 1999;158:785-788.

15. Akbayram S, Akgün C, Doğan M, Gündogdu M, Caksen $H$, Oner AF. Acquired methemoglobinemia due to application of prilocaine during circumcision. J Emerg Med 2012;43:120-1211.

16. Mansouri A. Methemoglobinemia. Am J Med Sci 1985;289:200-209.

17. Guay J. Methemoglobinemia related to local anesthetics: A summary of 242 episodes. Anesth Analg 2009;108:837-845.

18. Soeding $P$, Deppe $M$, Gehring $H$. Pulse-oximetric measurement of prilocaine-induced methemoglobinemia in regional anesthesia. Anesth Analg 2010;111:1065-1068. 